\title{
Species composition and seasonal succession of saprophagous calliphorids in a rural area of Córdoba, Argentina
}

\author{
MOIRA BATTAN HORENSTEIN ${ }^{1 *}$, ARICIO X. LINHARES ${ }^{2}$, BEATRIZ ROSSO $^{1}$ \\ and MARÍA D GARCÍA ${ }^{3}$
}

\author{
${ }^{1}$ Cátedra de Diversidad Animal I, Facultad de Cs. Ex., Fís. y Nat., Universidad Nacional de Córdoba \\ (Argentina) \\ ${ }^{2}$ Departamento de Parasitologia, Instituto de Biologia, Universidade Estadual do Campinas, SP (Brasil) \\ ${ }^{3}$ Departamento de Zoología y Antropología Física, Facultad de Biología, Universidad de Murcia (España)
}

\begin{abstract}
During 2004, four experiments were carried out, one each season, in order to determine the species composition and seasonal dynamics of Calliphoridae in a rural area of Córdoba (Argentina). Two pigs (Sus scrofa L.), weighing approximately $8 \mathrm{Kg}$ each, were used in each experiment. They were killed with a blow to the head and immediately placed in a variant of the Schoenly et al. (1991) trap. One pig was exposed in the shade and the other one under direct sunlight. The insect fauna was collected daily during the four first weeks and every two or three days thereafter. A total of 16.609 adults of Calliphoridae were collected, and later on identified as one of the following seven species: Chrysomya albiceps (Wiedemann), Chrysomya megacephala (Fabricius), Phaenicia sericata (Meigen), Phaenicia eximia (Wiedemann), Cochliomyia macellaria (Fabricius), Sarconesia chlorogaster (Wiedemann) and Calliphora vicina Robineau-Desvoidy. C. albiceps was the dominant species in summer, autumn and spring, being replaced in winter by $C$. vicina, $S$. chlorogaster and $P$. sericata. The analysis of the seasonal distribution of the species revealed that the greater incidences are in the months of summer, autumn and spring.
\end{abstract}

Key terms: calliphorids, necrophages, seasonal dynamics, succession.

\section{INTRODUCTION}

The species of arthropods associated to vertebrate carrion constitute a complex community in which five ecological categories can be identified: necrophages, parasites and predators of the necrophages species, omnivores, opportunists and adventives (Smith, 1986; Catts and Goff, 1992). When the arthropods colonize the carcasses, they do it in successional waves depending on the degree of carcass decomposition and the biogeographical region (Nuorteva, 1977; Smith, 1986). Dipteran families are the most abundant insects on carrion fauna, Calliphoridae being the first ones to arrive, followed by Sarcophagidae and Muscidae. They modify the physical and chemical conditions of carcasses allowing the colonization and establishment of species at later stages of the succession (Ricklefs, 1996). Calliphoridae species are necrophages and not only breed in carrion, but they also can breed on excrement or other types of organic matter and can be vectors of several animal and human diseases (Fischer et al., 2001). Some species cause myiasis in many animals, including man (Guimaraes et al., 1983). In addition, the knowledge of the sequence in which Calliphoridae species colonize carrion is very useful in forensic sciences, since calliphorids are often the first to arrive at corpses thus providing accurate estimates for time of death.

\footnotetext{
* Corresponding autor: Av. Vélez Sarsfield 299, Phone: (54-351) 4332090, Fax: (54-351) 4332097,

E-mail: moira_battan@yahoo.com.ar
} 
In South America, several studies on ecology and medico-legal importance of calliphorids are being done in Brazil (Moura et al., 1997; Souza and Linhares, 1997; Carvalho et al., 2000; Carvalho and Linhares, 2001). In Argentina, Mariluis and Schnack (1989, 1996), Mariluis et al. (1994) and Schnack et al. (1995) have worked on the ecology of calliphorids and the relationship of these blowflies with human activity. Only a few studies on the faunal associations related to stages of decomposition and their application in legal medicine were done by Oliva (1997) and Centeno et al. (2002), in eastern Argentina. Battán-Horenstein et al. (2005), carried out a preliminary study in Cordoba (central region) describing the global composition of the arthropod community associated to a chicken carcass during the spring. This is the first report of an ongoing study on calliphorid succession and seasonal dynamics occurring on pig carcasses in the same area. The aim of this work was to determine the composition and succession pattern of carrion calliphorids in Central Argentina.

\section{METHODOLOGY}

Four experiments were carried out during 2004, one per season, in the south of Córdoba city, Argentina, a zone characterized basically by the presence of carob trees (Prosopis alba and $P$. nigra). During the past one hundred years, this vegetation has been replaced by citrus, soybean and alfalfa crops. The regional climate includes dry and cold months during autumn (March-June) and winter (JuneSeptember), as well as warm and wet months during spring (September-December) and summer (December-March). The annual rainfall in this area is $800-1000 \mathrm{~mm}$. It is a rural zone with dense vegetation and isolated houses (Schnack, et al., 1998). The place was chosen because it represents a transition between natural and urban areas, and it is believed that diversity in this area should be high due to the contribution of species from the other two areas. In this investigation, two domestic pigs (Sus scrofa L.), approximately $8 \mathrm{~kg}$ each, were used for each of the four experiments. The pigs were killed with a blow to the head with a blunt metallic object and immediately placed in a variant of the trap designed by Schoenly et al. (1991) measuring 120 × 90 x $60 \mathrm{~cm}$ : one was placed under direct sunlight and the other in the shade, aproximately $300 \mathrm{~m}$ apart. The design of the trap makes possible to collect a large number of arthropods, those attracted to the carcass and those emerging from it. Each experiment lasted approximately 7 weeks, allowing the entire carcass to be consumed. Samples were taken daily during the first four weeks in order to collect Calliphoridae species and every 2 or 3 days in the subsequent weeks, until the end of the experiments. Relative humidity and temperature, both inside the traps and in the vicinity were recorded every day with a portable thermohygrometer (Hygro/In/Out Thermometer HT05, TFA/ Germany). The temperature of the carcass was taken by introducing the probe of the thermohygrometer into it, or into the larval mass when it was present. The corresponding meteorological data of the zone for all seasons were obtained from the nearest weather station.

A two way ANOVA was done, and the main factors were the frequency of fly species and the insolation regime. For each species, one-way ANOVAs were also performed to determine differences in fly abundance among seasons. The correlations between the captures of the four most abundant species and minimal, maximum, mean and carcass temperatures were also calculated. The ANOVAs were done using the PROC GLM (General Linear Models) procedure, and the correlations were done using the PROC CORR procedure of SAS (Statistical Analysis System), (SAS Institute, 1986).

\section{RESULTS}

A total of 16.609 adult calliphorids, belonging to seven species, was collected: Chrysomya albiceps, C. megacephala, Phaenicia sericata, P. eximia, Cochliomyia macellaria, Sarconesia chlorogaster and Calliphora vicina. Table 1 presents the absolute and relative frequency for each 
TABLE I

Frequency and seasonal percentages for each species of adult Calliphoridae collected in the four experiments. Different letter means significantly different $(\alpha=0,05)$.

\begin{tabular}{lccccc}
\hline Species & Experiment Summer & Autumn & Winter & Spring & Total \\
\hline Chrysomya albiceps & $7108(\mathrm{a})$ & $1012(\mathrm{a})$ & $9(\mathrm{c})$ & $5457(\mathrm{a})$ & 13586 \\
& 52.32 & 7.45 & 0.07 & 40.16 & 100 \\
C. megacephala & $2(\mathrm{~b})$ & $30(\mathrm{c}, \mathrm{d})$ & $0(\mathrm{c})$ & $0(\mathrm{e})$ & 32 \\
& 6.25 & 93.75 & 0 & 0 & 100 \\
Phaenicia sericata & $19(\mathrm{~b})$ & $77(\mathrm{~b})$ & $142(\mathrm{~b})$ & $452(\mathrm{~b})$ & 690 \\
& 2.75 & 11.16 & 20.58 & 65.51 & 100 \\
P. eximia & $0(\mathrm{~b})$ & $0(\mathrm{~d})$ & $0(\mathrm{c})$ & $16(\mathrm{~d}, \mathrm{e})$ & 16 \\
& 0 & 0 & 0 & 100 & 100 \\
Cochliomyia macellaria & $181(\mathrm{~b})$ & $32(\mathrm{c}, \mathrm{d})$ & $0(\mathrm{c})$ & $851(\mathrm{c})$ & 1064 \\
\multirow{2}{*}{ Sarconesia chlorogaster } & $5(\mathrm{~b})$ & 3 & 0 & 79.99 & 100 \\
& 0.62 & $37(\mathrm{~b}, \mathrm{c})$ & $698(\mathrm{a})$ & $71(\mathrm{c}, \mathrm{d})$ & 811 \\
Calliphora vicina & $0(\mathrm{~b})$ & 4.56 & 86.07 & 8.75 & 100 \\
& 0 & $3(\mathrm{~d})$ & $394(\mathrm{~b})$ & $13(\mathrm{e}, \mathrm{d})$ & 410 \\
& & 0.73 & 96.1 & 3.17 & 100 \\
\hline
\end{tabular}

species in the four experiments. It also shows the significant statistical differences in seasonal distribution for all species. The abundances of the species in the two insolation regimes were significantly different $(\mathrm{F}=5.0, \mathrm{p}=0.0255)$. The absolute frequency of the species in both conditions in each experiment is presented in Table 2.

\section{TABLE II}

Frequency of adult Calliphoridae reared under sun and shade in the four experiments. Different letter means significantly different $(\alpha=0,05)$.

\begin{tabular}{lcc}
\hline Species Condition & Sun & Shade \\
\hline Chrysomya albiceps & 4512 (a) & 9074 (a) \\
C. megacephala & 28 (a) & 4 (b) \\
Phaenicia sericata & 375 (a) & 315 (a) \\
P. eximia & $14(\mathrm{a})$ & 2 (b) \\
Cochliomyia macellaria & $563(\mathrm{a})$ & 501 (a) \\
Sarconesia chlorogaster & 414 (b) & 397 (a) \\
Calliphora vicina & 12 (b) & 398 (a) \\
\hline
\end{tabular}

Chrysomya albiceps was the most abundant calliphorid species in all four seasons, specially in the summer, followed by spring and autumn, showing low incidence during winter (Fig. 1). Although statistically there was no significant difference between the insolation regimes $(F=1.99, p=0.1592)$, there is a tendency of negative heliophily in this species, since $66.79 \%$ of the individuals were collected in the shade.

The second most abundant species was $C$. macellaria, specially during the spring (Fig. $2)$. This species did not show statistically significant difference in the heliophily, with similar abundances in the shade and under direct sunlight $(\mathrm{F}=0.05, \mathrm{p}=0.8274)$.

Sarconesia chlorogaster was present throughout the four seasons being the dominant species in winter, and showing a very low frequency during the rest of the seasons (Fig. 3). Although rearing this species in both regimes of insolation was rather similar (sun: 51.05\%, shade: $48.95 \%$ ), this difference, was statistically significant $(\mathrm{F}=7.77 ; \mathrm{p}=0.0056)$. 


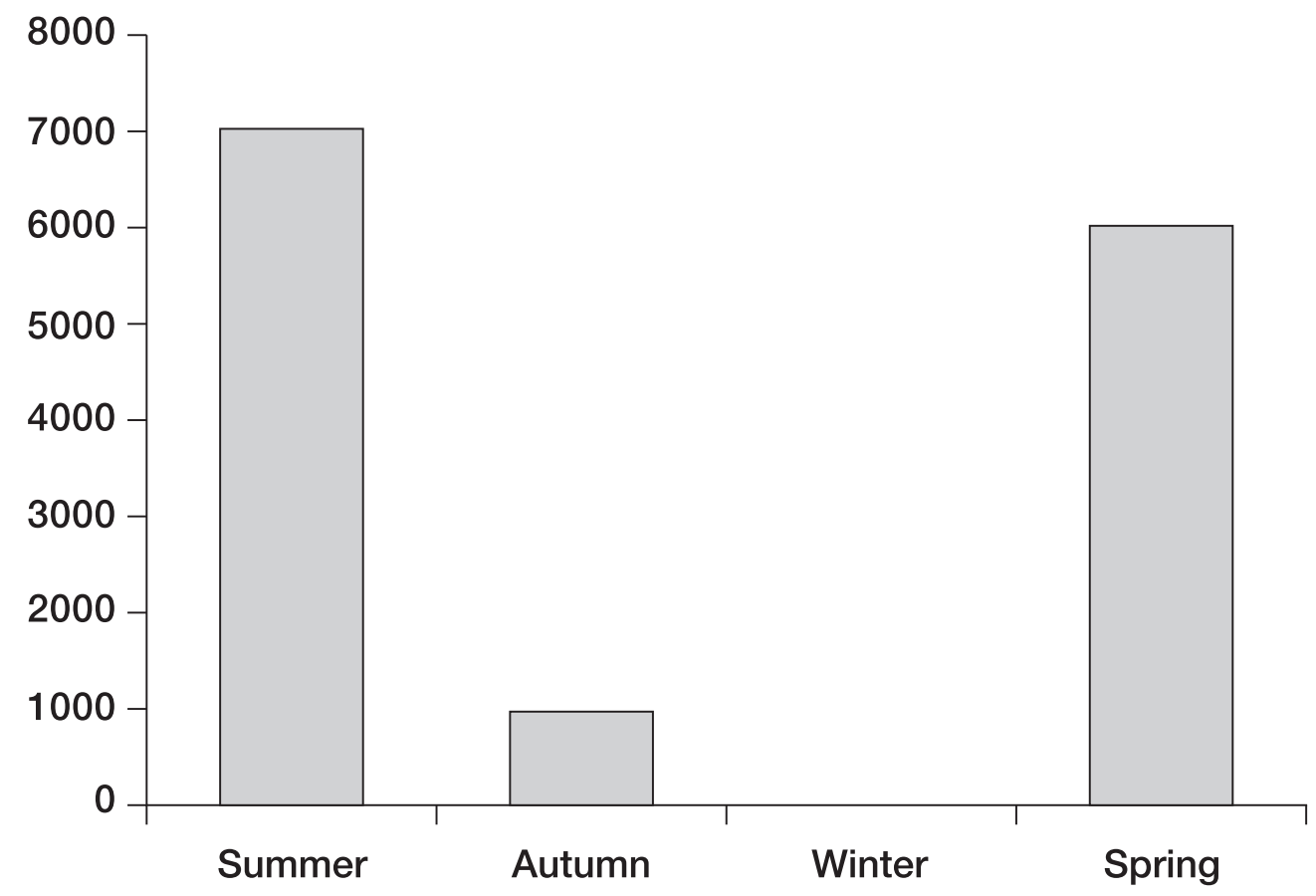

Fig. 1: Seasonal distribution of C. albiceps.

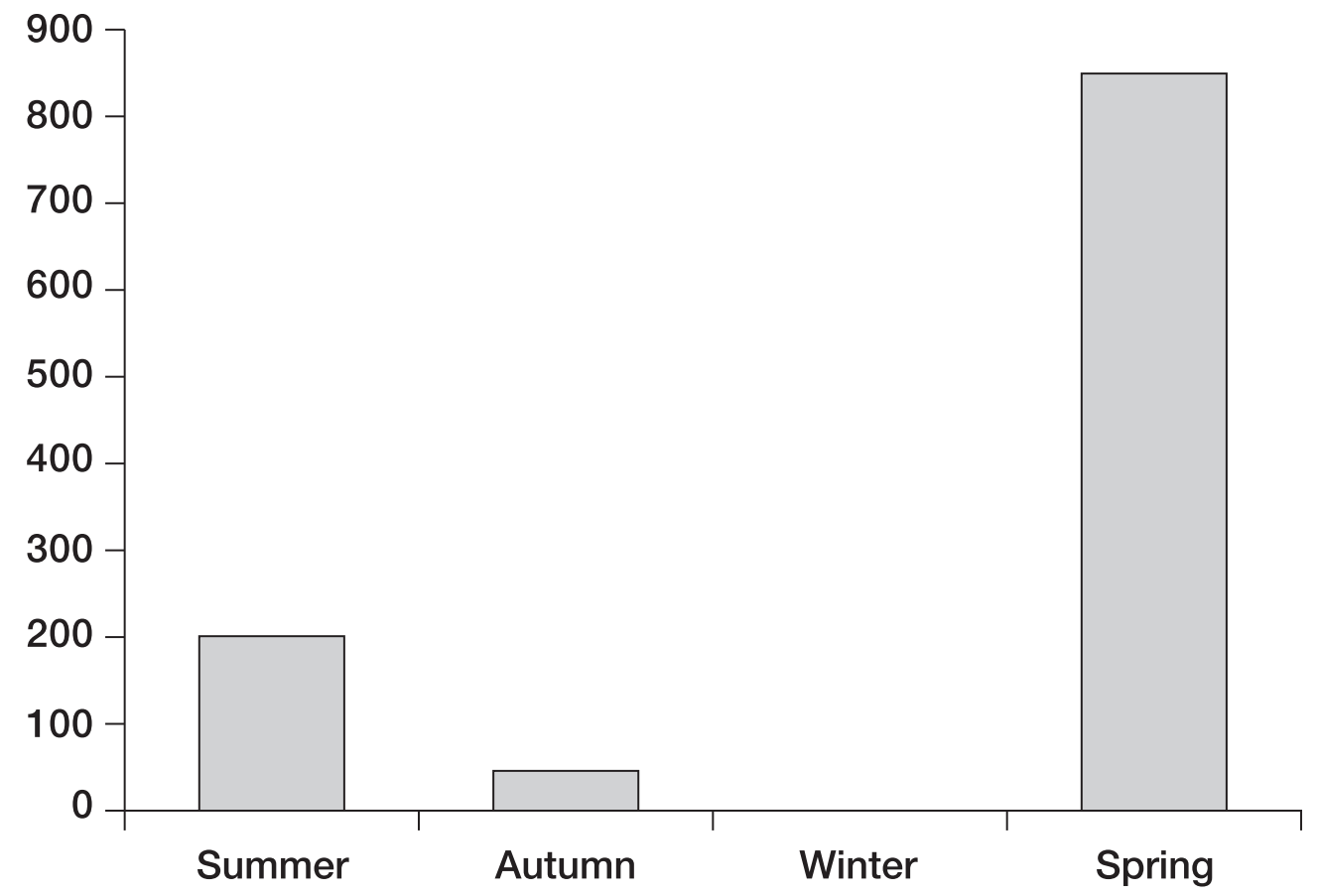

Fig. 2: Seasonal distribution of C. macellaria. 


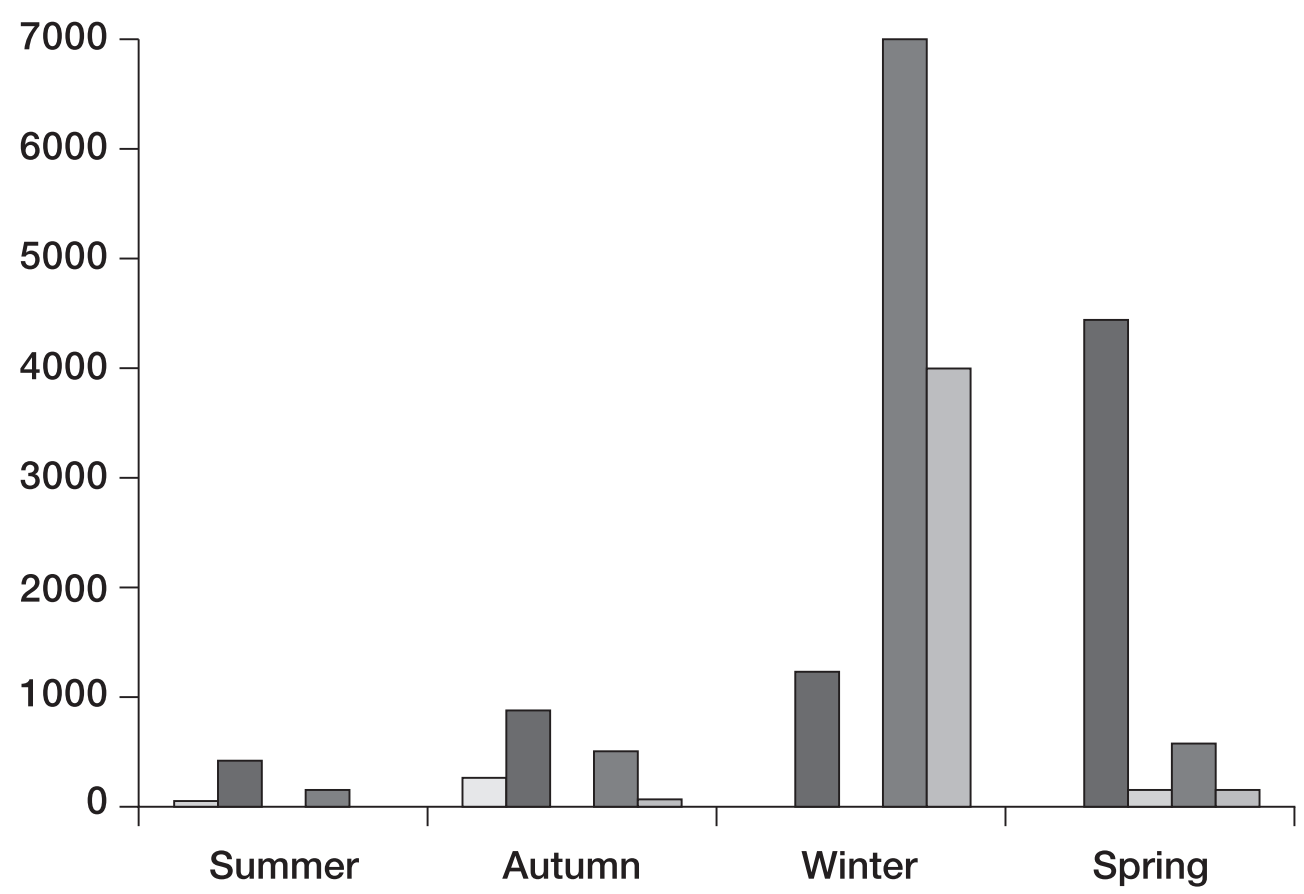

\section{C. megacephala P. eximia}

\section{Phaenicia sericata}

Sarconesia chlorogaster

\section{$\square$ Calliphora vicina}

Fig. 3: Seasonal distribution of the less abundant species of Calliphoridae.

The seasonal distribution of $C$. vicina showed that it is a species adapted to low temperatures, reaching a peak in winter, disappearing during the summer and reappearing in spring and autumn in very low percentages (Fig. 3). $97.07 \%$ of the individuals were collected in the shade, showing that these species present a notable negative heliophily $(\mathrm{F}=22.44, \mathrm{p}<0.0001)$.

Although $P$. sericata did not show significant differences among the different seasons (Table 1), it was most abundant in spring and, along with $S$. chlorogaster and C. vicina was also present during winter (Fig. 3). This species was collected in both insolation regimes $(\mathrm{F}=0.10, \mathrm{p}=0.7547)$.

Chrysomya megacephala and $P$. eximia, were collected in very low numbers. The first species was reared basically in autumn and the second only in spring (Fig. 3). Both species showed positive heliophily $(\mathrm{F}=8.32$, $\mathrm{p}=0.0042 ; \mathrm{F}=4.18, \mathrm{p}=0.0418$, respectively).
A close relation between the adult flies and the different stages of decomposition of carcasses was observed. Figures 4-6 show the succession pattern of the most abundant species in summer, spring and winter. In general two peaks of abundance of the species were observed throughout each season. The first one corresponded mainly to females that came to the carcass in search of a source for oviposition during first stage of decomposition, and the second to the emergence of males and females that developed from the eggs laid by those females attracted to the carcasses. It is important to point out that in summer and spring, C. macellaria showed only one peak of abundance, correspondent to the arrival of the adults. However, no emergence of adults of this species was observed. In winter, due to the low temperatures the process of decomposition was delayed and so were the attracted stages of the flies. Both, S. chlorogaster and C. vicina appeared late in this season. 


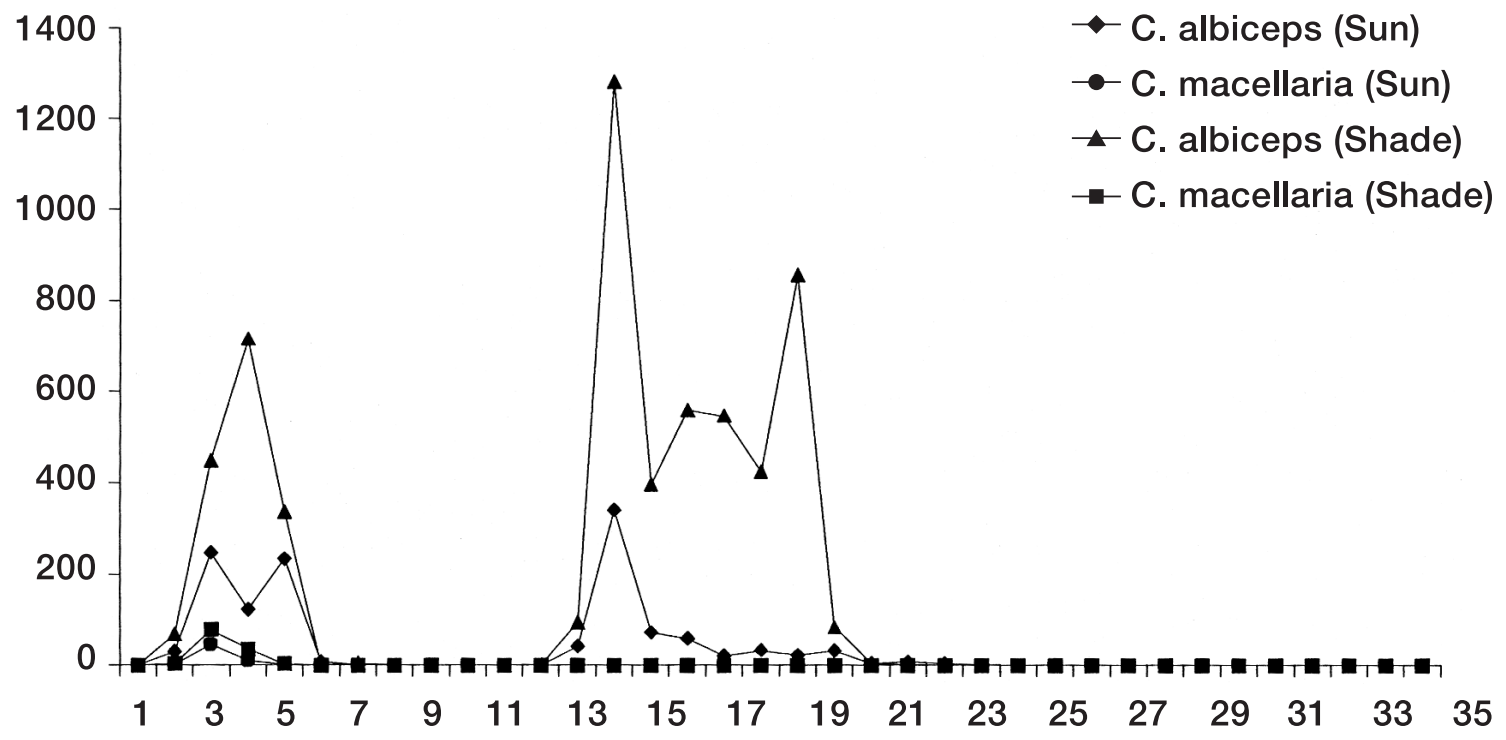

Fig. 4: Dynamics of arrival and eclosion of $C$. albiceps and $C$. macellaria in both insolation regimes in summer.

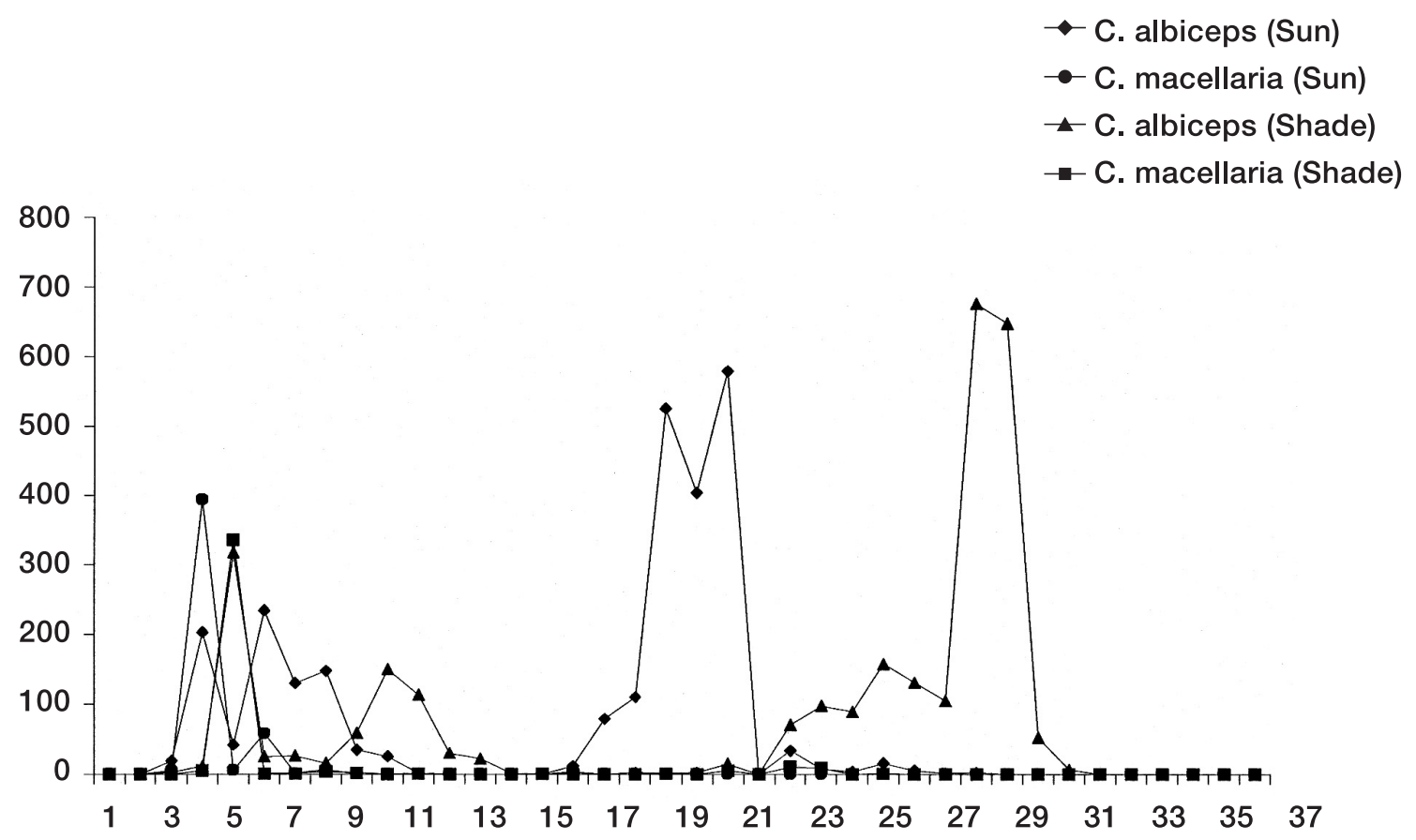

Fig. 5: Dynamics of arrival and eclosion of $C$. albiceps and $C$. macellaria in both insolation regimes in spring. 


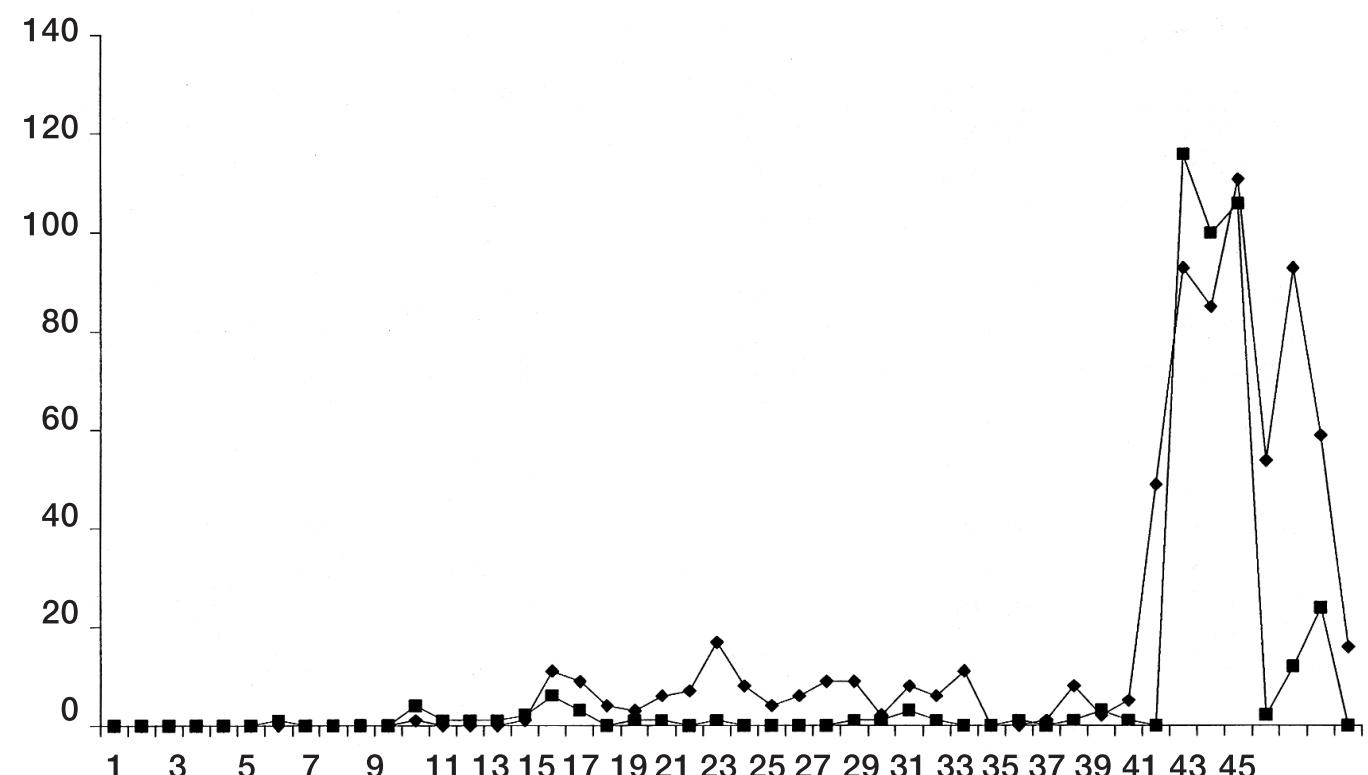

Fig. 6: Dynamics of arrival and eclosion of $S$. chlorogaster and C. vicina in both insolation regimes in winter.

The analysis of correlation made to test for the relationships among the abundances of the four most frequent calliphorid species and the maximun, minimum, mean and carcass temperatures, revealed a positive correlation between the seasonal variation of $C$. albiceps and $C$. macellaria with all four variables. Chrysomya albiceps showed a closer relationship with the temperature of the carcasses $(r=0.285$, $\mathrm{p}<0.0001)$ than with the other variables. On the other hand, $C$. macellaria showed a close association with the maximum temperature $\quad(\mathrm{r}=0.178, \quad \mathrm{p}=0.0011)$. Calliphora vicina and S. chlorogaster showed a negative correlation with temperatures. This result was expected due to the high abundance of these species found during winter months. Both species showed a significant relationship with the minimum and carcass temperatures: $C$. vicina $\left(\mathrm{T}^{\mathrm{o}} \min : \mathrm{r}=-0.131, \mathrm{p}=0.017 ; \mathrm{T}^{\mathrm{o}}\right.$ carcass: $\mathrm{r}=-0.129, \mathrm{p}=0.018)$ and $S$. chlorogaster $\left(\mathrm{T}^{\mathrm{o}} \min : \mathrm{r}=-0.198, \mathrm{p}=0.0003\right.$; $\mathrm{T}^{\mathrm{o}}$ carcass: $\left.\mathrm{r}=-0.186, \mathrm{p}=0.0007\right)$.

\section{DISCUSSION}

The results of this study showed different seasonal distribution of calliphorid species present in the area of study, fundamentally determined by temperature. The succession patterns and the abundance of the species in the experiment of each season, were not only influenced by the temperature, but also by other factors such as degree of carcass decomposition and intraspecific and interspecific competition.

Chrysomya albiceps was the most abundant species. Several authors (Linhares, 1981; Schnack et al., 1995; Ferreira and Barbola, 1998) determined the synanthropic indexes for this species. It was classified as hemisynantropic and with positive heliophily. A tendency towards negative heliophily was observed in this work, specially during the warmest months. It is important to point out that BattánHorenstein et al. (2005) working in the same area using a chicken carcass as bait during the spring of 2002, collected this 
species in very low percentage, and $P$. sericata was the species collected in higher numbers. Similar results were obtained by Souza and Linhares (1997). They attributed this difference to the size of the bait used. Apparently, C. albiceps, is attracted to larger animals to oviposit.

It is worth noting the low percentages of C. macellaria individuals collected, since this native species is well known to prevail in rural areas. Several authors (BattánHorenstein et al., 2005; Baumgartner and Greenberg, 1985; Schnack et al., 1995) have also observed this fact, and they attributed this decrease to the strong impact caused by Chrysomya species, recently introduced into the New World (Guimarães et al., 1978; Mariluis and Schnack, 1986).

The seasonal distribution of $C$. macellaria showed only one peak of abundance and no emergence of flies from the traps. Kuusela and Hanski (1982) suggested that competition is not a primary factor determining the structure of the fly community that breed in carrion. In contrast, we think that the absence of adult $C$. macellaria emerging from the carrion was due to the occurrence of strong competition between this species and $C$. albiceps, resulting in a possible intraguild predation of this last species on the first. Another hypothesis, would be that the previous presence of $C$. albiceps larvae on carcasses, could influence the ovipositional behavior of other blowflies, that could be able to choose patches with low risk of predation (WAC Godoy, personal communication $)^{1}$.

Gião and Godoy (unpublished observations), observed that $C$. megacephala and Lucilia eximia, laid less eggs when $C$. albiceps larvae were previously present, suggesting an ovipositional inhibition when their females faced $C$. albiceps larvae.

The low proportion of $P$. sericata collected could be attributed to its eusynanthropic character (Schnack et al., 1995). This species was present during the

\footnotetext{
Departamento de Parasitologia, Instituto de Biociências, Universidade Estadual Paulista, Botucatu, SP, Brasil.
}

four experiments, but it was reared from the carcass in relatively large frequency in spring, being also observed in the winter months in very low percentage. The annual distribution of this species in La Plata city, Buenos Aires Province (Argentina) ranges from the middle of November until the end of May (Mariluis and Schnack, 1986), being absent during winter. In Valdivia, southern Chile, Figueroa-Roa and Linhares (2002) collected individuals of this species in months of low temperatures but only in rural areas.

Sarconesia chlorogaster was present throughout the experiment but was particulary abundant in winter, coexisting with $C$. vicina. These results are coincident with those found by Moura et al. (1997) and Ferreira (1978) in southern Brazil.

Calliphora vicina, is a typical species of cold habitats, having a strong negative heliophily. Although this species was reared in a rural area, a great variation in its sinanthropy index has been observed, being collected both in urban (Figueroa-Roa and Linhares, 2002) and in natural environments (Schnack, 1995).

Phaenicia eximia had not been recorded for the Province of Córdoba, and was collected in low frequencies only during the spring. This species is very abundant in Brazil, both in the urban and rural zones (Ferreira and Barbola, 1998; Linhares, 1981) being dominant in spring and summer. It has been observed that this species presents a primary behavior in the successional process, developing quickly and leaving the carcass earlier than the other species, thereby avoiding a possible predation by third instar larvae of $C$. albiceps (AX Linhares, personal communication $)^{2}$.

C. megacephala was collected in very low proportion. Mariluis and Schnack (1986) collected this species in a rural area of Buenos Aires, but in low proportion when compared to $C$. albiceps. This proportion was the opposite in the urban zone. It is possible that the low abundances of this fly

\footnotetext{
Departamento de Parasitologia, Instituto de Biologia, Universidade Estadual Campinas, SP, Brasil.
} 
reared from the carcasses in this study, are due to its high degree of synanthropy, or because it prefers to utilize another kind of substrate (Linhares and Avancini, 1988). It is important to point out that there are no previous data on the frequency of $C$. megacephala for the study area.

\section{ACKNOWLEDGEMENTS}

Our gratitude to Dr. Patricia J. Thyssen and Dr. Wesley A.C. Godoy for their helpful suggestions on the manuscript.

\section{REFERENCES}

BATTÁN HORENSTEIN M, ARNALDOS MI, ROSSO B, GARCÍA MD (2005) Estudio preliminar de la comunidad sarcosaprófaga en Córdoba (Argentina): aplicación a la entomología forense. Anales de Biología 27: 191-201

BAUMGARTNER DL， GREENBERG B (1985) Distribution of medical ecology of the blowflies (Diptera: Calliphoridae) of Peru. Annals of Entomological Society of America 78: 565-587

CARVALHO LML, LINHARES AX (2001) Seasonality of insect seccession and pig carcass decomposition in a natural forest area in southeastern Brazil. J Foren Sci 46(3): 604-608

CARVALHO LML, THYSSEN PJ, LINDARES AX, PALHARES FAB (2000) A checklist of arthropods associated with pig carrion and human corpses in southeastern Brazil. Mem Inst Oswaldo Cruz 95(1): 135-138

CATTS EP, GOFF ML (1992) Forensic Entomology in Criminal Investigation. Annu Rev Entomol 37: 253-72

CENTENO N, MALDONADO M, OLIVA A (2002) Seasonal patterns of arthropods ocurring on sheltered and unsheltered pig carcasses in Buenos Aires Province (Argentina). Forensic Sci Internat 126: 63-70

FERREIRA MJM (1978) Sinantropía de dípteros muscóideos de Curitiba, Paraná. I: Calliphoridae. Rev Bras Biol 38: 445-454

FERREIRA MJM, BARBOLA IF (1998) Sinantropia de Califorídeos (Insecta: Diptera) de Curitiba, Paraná, Brasil. Rev Brasil Biol 58(2): 203-209

FISCHER OL, MÁTLOVÁ, DVORSKÁ L, SVÁSTOVÁ P, BARTL J, MELICHÁREK I, WESTON RT, PAVLÍK I (2001) Diptera as vector of mycobacterial infections in cattle and pigs. Med Vet Entomol 15: 208-211

GUIMARÃES JH, PRADO AP, LINHARES AX (1978) Three newly introduced blowfly species in southern Brazil (Diptera: Calliphoridae). Rev Bras Ent 22, 53-60 GUIMARÃES JHG, PAPAVERO N, PRADO AP (1983)
As miíases na região Neotropical: Identificação, biologia, bibliografia. Rev Bras Zool I: 239-416

KUUSELA S, HANSKI I (1982) The structure of carrion fly comminities: the size and the type of carrion. Holartica Ecology 5, 337-348

LINHARES AX (1981) Synanthropy of Calliphoridae and Sarcophagidae (Diptera) in the city of Campinas, Sao Paulo, Brazil. Rev Bras Ent 25(3): 189-215

MARILUIS JC, SCHNACK JA (1986) Ecología de una taxocenosis de Calliphoridae del área platense (Provincia de Buenos Aires) (Insecta, Diptera). Ecosur 12/13 (23/24): 81-91

MARILUIS JC, SCHNACK JA (1989) Ecology of the blow flies of an eusynanthropic habitat near Buenos Aires (Diptera, Calliphoridae). Eos 165: 93-101

MARILUIS JC, SCHNACK JA, CERVERERIZZO I, QUINTANA C (1994) Cochliomyia hominivorax (Coquerel, 1858) and Phaenicia sericata (Meigen, 1826) parasiting domestic animals in Buenos Aires and vicinities (Diptera, Calliphoridae). Mem Inst Oswaldo Cruz 89: 139. 32: 7-24

MARILUIS JC, SCHNACK JA (1996) Elenco específico y aspectos ecológicos de Calliphoridae (Insecta, Diptera) de San Carlos de Bariloche, Argentina. Bol R Soc Esp Hist Nat (Sec. Biol.) 92: 1-4

MOURA MO, CARVALHO CJB, MONTEIRO FILHO ELA (1997) A preliminary analisis of insects of medico-legal importance in Curitiba, State of Paraná. Mem Inst Oswaldo Cruz Vol. 92(2): 269-274

NUORTEVA P (1977) Sarcosaprophagous insects as forensic indicators. En: TEDESCHI, C.G., ECKERT, W.G. \& TEDESCHI, L.G. (Eds.) Forensic Medicine: A study in trauma and environmental hazards. Vol III. Philadelphia, London W.B. Saunders Co. 1072-1095

OLIVA A (1997) Insectos de Interés Forense de Buenos Aires (Argentina). Primera lista ilustrada y datos bionómicos. Revista de Museo argentino de Ciencias Naturales "Bernardino Rivadavia". Entomología, Tomo VII, $\mathrm{N}^{\circ}$ 2: 13-59

RICKLEFS R (1996) Invitación a la Ecología. La economía de la naturaleza. Editorial Médica Panamericana

SAS INSTITUTE INC (1986) SAS User's guide: Statictics, 6 ed. Cary, North Carolina

SCHNACK JA, MARILUIS JC, CENTENO N, MUZÓN J (1995) Composición específica, ecología y sinantropía de Calliphoridae (Insecta: Diptera) en el Gran Buenos Aires. Rev Soc Entomol Argent 54 (1-4): 161-171

SCHNACK JA, MARILUIS JC, SPINELLI GR, MUZÓN J (1998) Ecological aspects on urban blowflies in midwest Argentinean Patagonia (Diptera: Calliphoridae). Rev Soc Entomol Argent 57 (1-4): 127-130

SCHOENLY K, GRIEST K, RHINE S (1991) An experimental field protocol for investigating the postmortem interval using multidisciplinary indicators. J Forensic Sci JFSCA, Vol. 36, n ${ }^{\circ}$ 5, pp. 1395-1415

SMITH KGV (1986) A manual of forensic entomology. The trustees of the British Museum (Natural History), London

SOUZA AM, LINHARES AX (1997) Diptera and Coleoptera of potential forensic importance in southeastern Brazil: relative abundance and seasonality. Med Vet Entomol 11: 8-12 
